\title{
Sclerostin: a biomarker for chronic kidney disease and vascular disease with added or independent value?
}

\author{
Marijan Bosevski ${ }^{1}$ (D
}

Received: 16 August 2018 / Accepted: 20 August 2018 / Published online: 4 September 2018

(c) Springer Nature B.V. 2018

\section{Editor,}

Many studies through the previous and the current decade implicate that bone and mineral abnormalities in chronic kidney disease (CKD) may contribute to the presence of vascular disease (VD), with the most likely link being the presence of vascular calcification [1]. Sclerostin is one of these biomarkers, aptly named, as the link between bone and vascular disease [2].

In a recent study by Figurek and Spasovski, a trend of declining sclerostin levels emerges in patients with CKD and significantly higher carotid intima-media thickness (CIMT) levels [3]. However, it is important to note that serum sclerostin was not associated with CIMT [3]. Furthermore, Kanbay's meta-analysis demonstrated no association between serum sclerostin levels and all-cause as well as cardiovascular mortality [4].

Multiple regression analysis that included sex, glomerular filtration rate (GFR), age, body mass index, serum calcium and serum phosphorus indicated that GFR, gender and serum phosphate were associated with serum sclerostin [5]. Other researchers have reported that serum sclerostin increases with ageing [6].

Ageing, on the other hand, is an independent risk factor for VD, measured as CIMT and carotid plaques. Studies on general and diabetic populations reveal these results $[7,8]$.

This begs the following question: whether sclerostin has an independent or an added value to the process of ageing, in vascular disease, when measured with carotid ultrasound? Could authors possibly give an answer?

\section{References}

1. Raggi P, Kleerekoper M (2008) Contribution of bone and mineral abnormalities to cardiovascular disease in patients with chronic kidney disease. Clin J Am Soc Nephrol 3(3):836-843

2. Bruzzese A, Lacquaniti A, Cernaro V et al (2016) Sclerostin levels in uremic patients: a link between bone and vascular disease. Ren Fail 38(5):759-764

3. Figurek A, Spasovski G (2018) Is serum sclerostin a marker of atherosclerosis in patients with chronic kidney disease-mineral and bone disorder? Int Urol Nephrol. https://doi.org/10.1007/ s11255-018-1935-5

4. Kanbay M, Solak Y, Siriopol D et al (2016) Sclerostin, cardiovascular disease and mortality: a systematic eview and meta-analysis. Int Urol Nephrol 48(12):2029-2042

5. Kirkpantur A, Balci M, Turkvatan A et al (2015) Independent association between serum sclerostin levels and carotid artery atherosclerosis in prevalent haemodialysis patients. Clin Kidney J 8(6):737-743

6. Mödder UI, Hoey KA, Amin S et al (2011) Relation of age, gender, and bone mass to circulating sclerostin levels in women and men. J Bone Miner Res 26:373-379

7. Bosevski M (2014) Carotid artery disease in diabetic patients. Pril (Makedon Akad Nauk Umet Odd Med Nauki) 35(3):149-161

8. Hedblad B, Nilsson P, Janzon L et al (2000) Relation between insulin resistance and carotid intima-media thickness and stenosis in non-diabetic subjects. Results from a cross-sectional study in Malmö, Sweden. Diabet Med 17(4):299-307
Marijan Bosevski

marijanbosevski@yahoo.com

1 Saints Cyril and Methodius University of Skopje, Skopje, Macedonia 